\title{
EFFECTS OF ARTIFICIAL DIETS ON THE BIOLOGICAL CYCLE OF Condylorrhiza vestigialis
}

\author{
Cacilda João Chirinzane ${ }^{1}$, Nilton José Sousa ${ }^{1}$, Eduardo Henrique Rezende ${ }^{1}$, Antonio Carlos Batista ${ }^{1}$, Marcos \\ Giongo $^{2}$, Veruza Cristina Mendonça ${ }^{1}$ \\ ${ }^{1}$ Federal University of Paraná - Department of Forest Engineering, Curitiba, Paraná, Brazil cacildachirinzane@ gmail.com; \\ nilton.ufpr@gmail.com; *eduardorezende114@gmail.com; batistaufpr@gmail.com; *veruzamendonca@ gmail.com; \\ ${ }^{2}$ Federal University of Tocantins, Department of Forest Engineering, Gurupi, Tocantins, Brazil, giongo@uft.edu.br.
}

Received for publication: 24/06/2019 - Accepted for publication: 08/10/2020

\begin{abstract}
Resumo
Efeitos de dietas artificiais no ciclo biológico de Condylorrhiza vestigialis. O objetivo deste trabalho foi determinar a influência de diferentes dietas artificiais nos parâmetros biológicos relacionados ao ciclo de vida de Condylorrhiza vestigialis visando determinar a dieta mais adequada para a criação em laboratório de uma população deste inseto. Foram testadas quatro formulações, de dieta. Foram utilizadas 10 repetições, com 30 lagartas por repetição. Foram acompanhadas todas as etapas do ciclo de vida de $C$. vestigialis para avaliação dos parâmetros biológicos: viabilidade de larvas, pré pupa, pupa e adultos, bem como a razão sexual. Foi calculado também o número de instares larvais, a massa de pupas e o número de ovos total, por dia e por dia fêmea. As quatro dietas testadas possibilitaram o desenvolvimento das lagartas de C. vestigialis. Todas as dietas foram consideradas adequadas a finalidade do trabalho, que é a produção do baculovirus utilizado no programa de controle desta praga. A dieta 2 é que proporcionou melhores resultados, maior massa de pupas, e quantidade e viabilidade dos ovos produzido por fêmeas de $C$. vestigialis que na fase larval são alimentadas com esta dieta. Palavras chaves: Laboratório, Mariposa do Álamo, criação massal.
\end{abstract}

\begin{abstract}
Absctract
The objective of this work was to determine the influence of different artificial diets on biological parameters related to the life cycle of $\mathrm{C}$ Condylorrhiza vestigialis aiming to determine the most suitable diet for the rearing of a population of this insect. Four diet formulations were tested. Ten repetitions were used, with 30 caterpillars per repetition. All stages of $C$. vestigialis life cycle were followed to evaluate biological parameters: viability of larvae, pre pupa, pupa and adults, as well as the sex ratio. The number of larval instars, the pupal mass and the total number of eggs per day and per female day were also calculated. The four diets tested allowed the development of $C$. vestigialis caterpillars. All diets were considered adequate for the purpose of the work, which is the production of baculovirus used in the control program of this pest. It was the diet 2 that provided the best results, the largest pupal mass, and the quantity and viability of the eggs produced by $C$. vestigialis females fed in this larval phase.

Keywords: Laboratory, Poplar Moth, mass breeding.
\end{abstract}

\section{INTRODUCTION}

Populus deltoides (Álamo), originally from eastern North America, is widely cultivated worldwide for the production of wood, bridge beams, fence posts, afforestation and landscaping. In Brazil it has been used as raw material for the matchstick industry, with plantations concentrated in the south of the State of Paraná and some municipalities in the north of the State of Santa Catarina (MACHADO, 2017).

One of the factors that affect the productivity of $P$. deltoides is the occurrence of pests, among them the main one is Condylorrhiza vestigialis (Mariposa do Álamo). In the larval phase, this insect causes intense defoliation in P. deltoides plants and consequently reduced productivity (MACHADO, 2017). Marques et al. (1995), reveal that the poplar moth caused several damages to Populus stands in plantations carried out in southern Paraná, with defoliation levels of up to $100 \%$ in the nurseries, and in adult trees, the defoliation level can reach higher levels to $50 \%$.

Among the methods of control of C. vestigialis, the use of the fungus Beauveria bassiana is one of the alternatives (POGETTO; WILCKEN, 2012), but the use of the entomapotogenic virus Condylorrhiza vestigialis multiple nucleopolyhedrovirus (CoveMNPV), extracted from the insect itself, is one of the that stand out the most, for its high efficiency characteristic and for being specific for this pest (CASTRO et al., 2009; CASTRO, 2011). The large-scale production of the product used in the control, demands a large amount of viruses for its manufacture, being necessary to establish creations of this insect in the laboratory, using artificial diets (MACHADO, 2017). In addition, with laboratory creations, other studies are also feasible, such as those with sexual pheromones, which are already carried out with C. vestigialis (AMBROGUI et al., 2009).

In this sense, some studies have been performed to identify the best diet for the creation of C. vestigialis in the laboratory during the larval phase, in view of the constant need for its entomapatogenic virus in programs

FLORESTA, Curitiba, PR, v. 51, n. 1, p. 146-153, jan/mar 2021.

Chirinzane, C. J. et.al.

ISSN eletrônico 1982-4688

DOI: $10.5380 /$ rf.v51 i1. 67580 
to control this pest (CAMPOS et al., 2017). However, the improvement in the techniques of creation of C. vestigialis must always be promoted, in view of the constant demand for the virus extracted from this insect.

The differences contained in the formulations of the diets offered to insects, can cause effects on the parameters related to their life cycle, in their different stages of development, in laboratory creations as verified in the studies of Arioli et al., 2010; Bortoli et al., 2014; Bortoli et al., 2015.

Thus, the objective of this work was to determine the influence of different artificial diets on the biological parameters related to the life cycle of $C$. vestigialis, aiming to determine the most suitable diet for the creation in the laboratory of a population of this insect.

\section{MATERIAL AND METHODS}

In the experiments of this work, caterpillars of the $\mathrm{F} 2$ generation of $\mathrm{C}$. vestigialis were used, coming from a mass creation of the Forest Protection laboratory of the Department of Forest Sciences of the Federal University of Paraná, specially developed for this purpose. The biological materials that started this creation were randomly collected in nurseries and plantations of Populus spp., it is located in the municipalities of São Mateus do Sul - PR and Porto União - Santa Catarina.

Four formulations of artificial diets were tested. The diets tested were adaptations of the diet used to create Diatraea saccharalis (Fabr.) (Lepidoptera, Crambidae), developed by Parra and Mihsfeldt (1992). (Table 1). The choice of the diet of Parra and Mihsfeldt (1992), as a basis for the changes, considered two factors. The first was biological, as C. vestigialis and D. saccharalis belong to the Crambidae family. The second factor was financial, since the formulation of the D. saccharalis diet has less complexity and cost than the other tested and used beds for the creation of C. vestigialis in the laboratory.

Table 1. Components used in the artificial diets tested for the creation of $C$. vestigialis under laboratory conditions. Tabela 1. Componentes utilizados nas dietas artificiais testadas para a criação de C. vestigialis em condições de laboratório.

\begin{tabular}{ccccc}
\hline Component & \multicolumn{5}{c}{ Quantity/diet } \\
\cline { 2 - 5 } & 1 & 2 & 3 & 4 \\
\hline Water (mL) & 500 & 500 & 500 & 500 \\
Agar (g) & 9 & 9 & 9 & 9 \\
Ascorbic acid (g) & 2,14 & 2,14 & 2,14 & 2,14 \\
Cornflour (g) & 60 & 60 & 60 & 60 \\
Wheat germ (g) & 15 & 15 & 15 & 15 \\
Brewer's yeast (g) & 16 & 16 & 16 & 2,14 \\
Nipagin & 2,14 & 2,14 & 2,14 & 5,7 \\
(methylparahydroxybenzoate) (g) & - & 5,7 & 5,7 & 64 \\
Populus Leaves (g) & - & - & 64 & 4 \\
Juice V8 $8^{(1)}(\mathrm{g})$ & - & - & - & \\
Vitamin complex (2) $(\mathrm{mL})$ & - & & & 16 \\
\hline
\end{tabular}

NOTE: Composition of the vitamin complex: Niacinamide $1.0 \mathrm{~g}$, Calcium pantothenate $1.0 \mathrm{~g}$, Riboflavin $1.50 \mathrm{~g}$; Thiamine HCl $0.25 \mathrm{~g}$, Pyrodoxin $\mathrm{HCl} 0.25 \mathrm{~g}$, Folic acid $0.10 \mathrm{~g}$, Biotin $0.02 \mathrm{~g}$, Vitamin B12 $0.002 \mathrm{~g}$.

The differences in diets were that in diets 2, 3 and 4 were added leaves of Populus; in the 3 and 4 the juice V8 was added and in the diet 4 , the vitamin complex.

For each diet, 10 repetitions were used, with 30 caterpillars per repetition. The postures performed by adult moths on white paper (sulfite) were cut with scissors, the eggs were counted with the help of a magnifying glass, and then stapled to the sides of the cups and kept in a climate-controlled chamber (BOD) with a temperature of $25 \pm 2{ }^{\circ} \mathrm{C}$ and relative humidity of $60 \pm 10 \%$. Then, $3 \mathrm{~cm}$ (length) $\mathrm{x} \mathrm{cm}$ (width) $\mathrm{x} 1 \mathrm{~cm}$ (thickness) diet cubes were left inside the egg containers.

After the caterpillars hatched, a caterpillar was removed daily, randomly, per container, and placed on a slide inside petri dishes, totaling 10 caterpillars per day per diet. In the caterpillars collected daily, the width of the cephalic capsule was measured by means of a graduated micrometric eyepiece, coupled with a stereomicroscope.

The pupae from the starts were packed in PVC tubes, $14.5 \mathrm{~cm}$ in diameter and $15.5 \mathrm{~cm}$ high, packed in BOD, $25 \pm 2{ }^{\circ} \mathrm{C}$ and relative humidity of $60 \pm 10 \%$ for later emergence of adults . Pupae mass was calculated by weighing 100 pupae per tested diet.

After emergence, adults of $\mathrm{C}$. vestigialis were counted and separated by sex in a proportion of 2: 1 per PVC tube, being fed with a solution of honey $(10 \mathrm{ml})$, distilled water $(100 \mathrm{ml})$, and sugar $(60 \mathrm{~g})$. 
10 males and 5 females were used per repetition, with 5 repetitions. The breeding tubes were lined with sulfite paper internally, with the upper end of the tube covered with a fine mesh net, secured with elastic. Daily, the bond paper placed in the tubes was exchanged, together with the adult food and the fine mesh, on bond paper was deposited all the eggs of the laying performed by the females, these were observed and counted with a magnifying glass.

With the measurements obtained from the brain capsules during the larval period, the number of instars was calculated, with the selection of clusters that presented similar values, over time, where each peak of the multimodal frequency distribution curve represents an instar.

The data collected from the biological parameters of duration of each phase of the life cycle were subjected to analysis of variance (ANOVA), with the means being compared by the Tukey test, at the level of 5\% probability of error. The viability of larvae, pre-pupa, pupa, adults, and eggs was calculated and compared between diets. The sex ratio was also obtained, calculated according to Silveira Neto et al. (1976). With the daily recording of the number of eggs in each repetition, it was possible to determine the total number of eggs per day, in each tube, and thus obtain the average number of eggs per female / day created in the tested artificial diets.

\section{RESULTS}

For all diets tested, five homogeneous groups of peaks were observed by analyzing the multimodal frequency curve of the cephalic capsule width of C. vestigialis, indicating the existence of five larval instars (Figure $1)$.

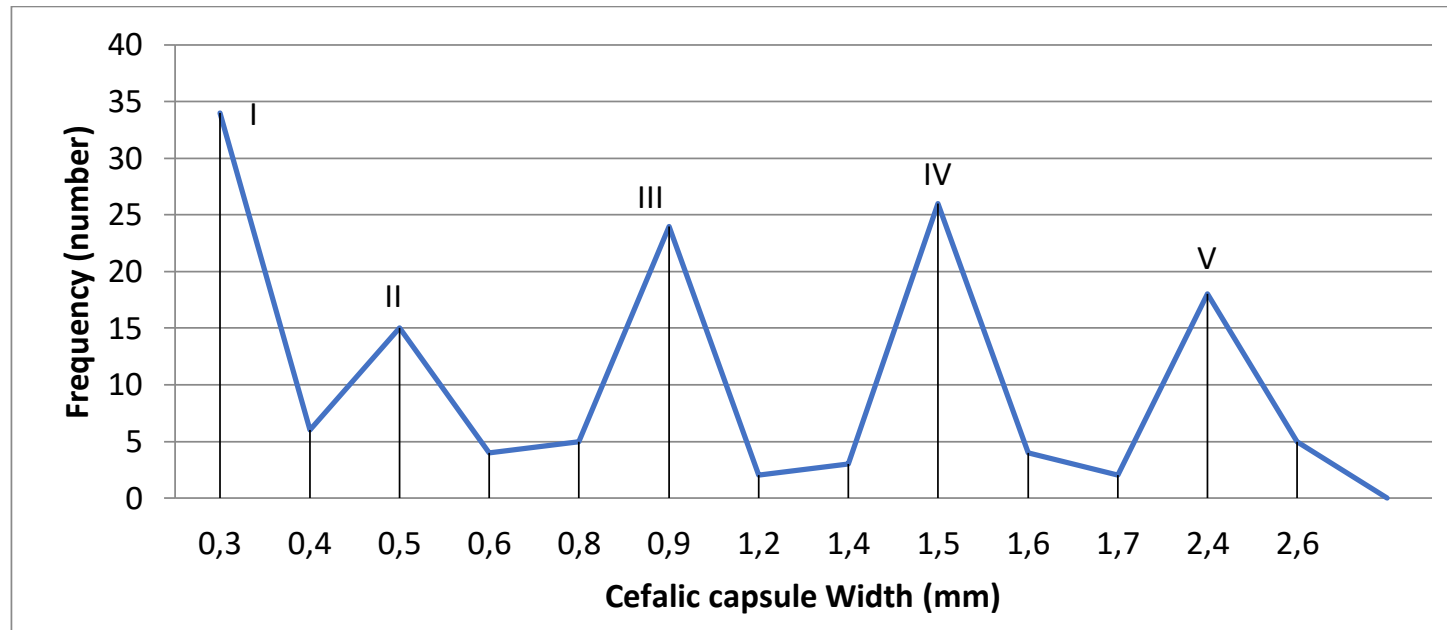

Diet 1

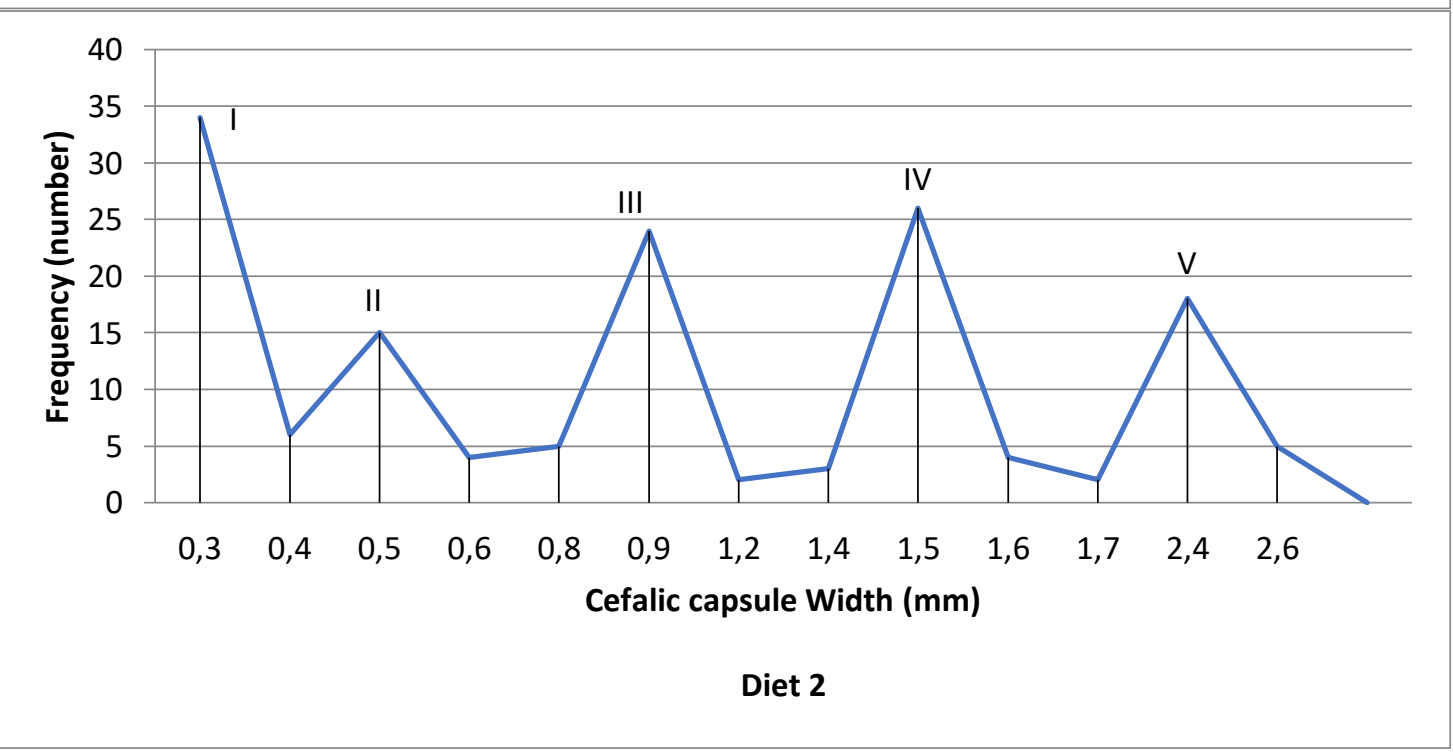

FLORESTA, Curitiba, PR, v. 51, n. 1, p. 146-153, jan/mar 2021.

Chirinzane, C. J. et.al. 


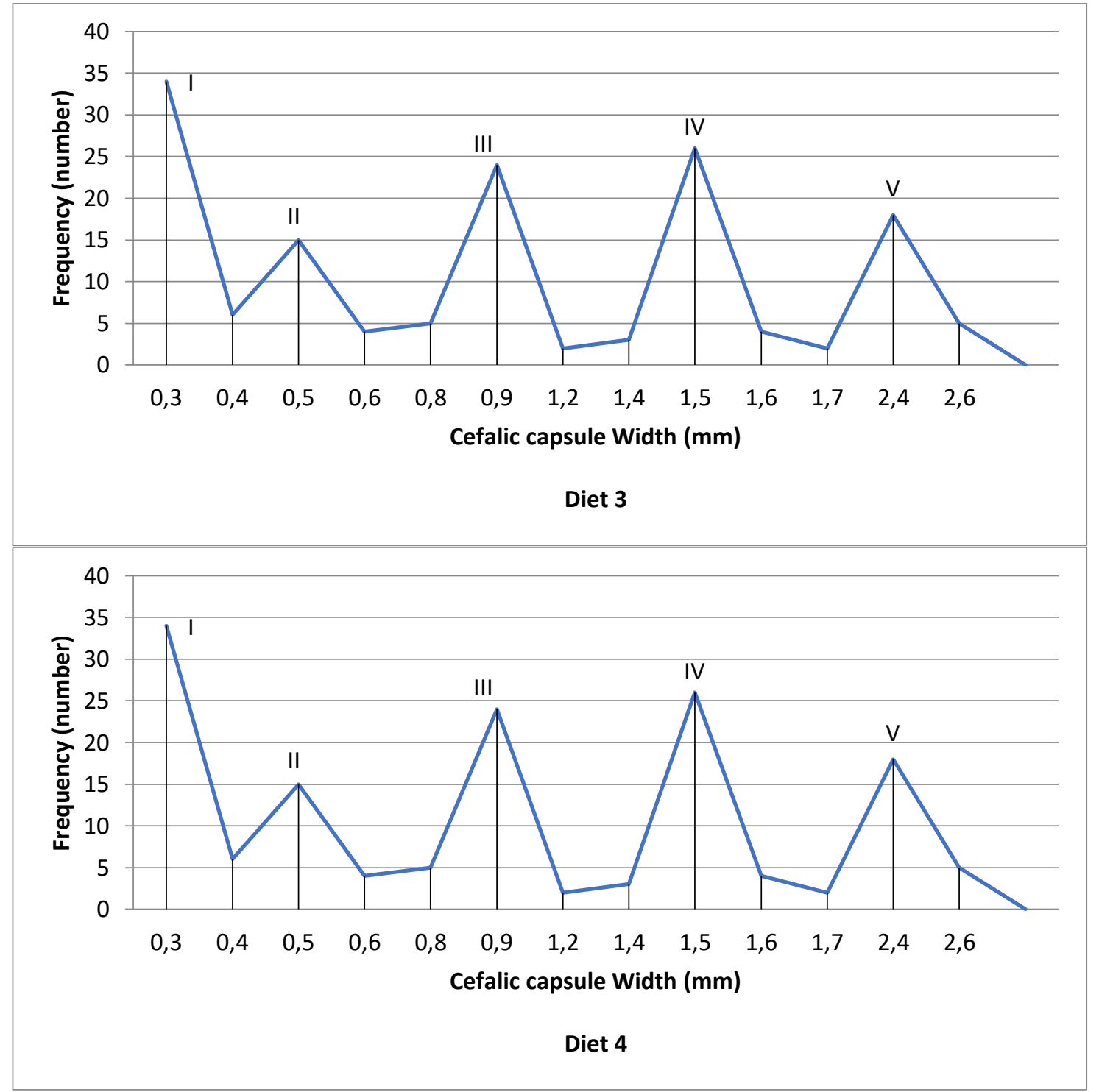

Figure 1. Number of larval instars according to the cephalic capsule peaks of $C$. vestigialis larvae fed with the different diets tested.

Figura 1. Número de ínstares larvais de acordo com os picos de medidas das cápsulas cefálicas de larvas de $C$. vestigialis alimentadas com as diferentes dietas testadas.

Table 2 shows the duration of each stage of the life cycle of C. vestigialis, when fed with the four different diets. It is observed that the total larval period was 18.35 days; 17.01 days; 17.75 days and 17.57 days, according to the diet used from 1 to 4respectively (Table 1).

Table 2. Duration of the life cycle stages of $C$. vestigialis: larvae, pre-pupae, pupa and adults, whose larvae were fed the different artificial diets tested.

Tabela 2. Duração das etapas do ciclo de vida de $C$. vestigialis: larva, pré-pupa, pupa e adultos, cuja larvas foram alimentadas com as diferentes dietas artificiais testadas.

\begin{tabular}{cccccc}
\hline Diets & Larva & Pre-pupa & Pupa & Female Adult & Male Adult \\
\hline DIET 1 & $18,35 \pm 0,09 \mathrm{c}$ & 1 & $9,22 \pm 0,09 \mathrm{a}$ & $12,6 \pm 0,008 \mathrm{~b}$ & $13,74 \pm 0,009 \mathrm{~b}$ \\
DIET 2 & $17,01 \pm 0,01 \mathrm{~b}$ & 1 & $7,12 \pm 0,02 \mathrm{~b}$ & $13,6 \pm 0,004 \mathrm{a}$ & $15,08 \pm 0,013 \mathrm{a}$ \\
DIET 3 & $17,75 \pm 0,01 \mathrm{ab}$ & 1 & $9,04 \pm 0,02 \mathrm{a}$ & $12,2 \pm 0,013 \mathrm{~b}$ & $14,6 \pm 0,004 \mathrm{a}$ \\
DIET 4 & $17,57 \pm 0,01 \mathrm{ab}$ & 1 & $8,97 \pm 0,01 \mathrm{a}$ & $12,58 \pm 0,004 \mathrm{~b}$ & $15 \pm 0,008 \mathrm{a}$ \\
\hline
\end{tabular}

NOTE: Data transformed into: $\log (x+0.5)$.

Means followed by the same letter in the columns do not differ statistically from each other, at the level of $5 \%$ probability by the Tukey test.

FLORESTA, Curitiba, PR, v. 51, n. 1, p. 146-153, jan/mar 2021.

Chirinzane, C. J. et.al.

ISSN eletrônico 1982-4688

DOI: $10.5380 /$ rf.v51 i1. 67580 
The pre-pupal stage is the stage when the caterpillars stop feeding. This phase lasted one day for all tested diets. The pupa phase duration was 9.22 days; 7.12 days; 9.04 days and 8.97 days according to the diet used, respectively from 1 to 4 (Table 2).

The duration of adult females (adult emergence until death) was shorter than that of males. Females originating from caterpillars fed with diets 1,3 and 4 showed average values in days of $12.6 \pm 0.008,12.2 \pm 0.013$ and $12.58 \pm 0.004$, respectively, with no statistically significant differences between them. However, they differed from females whose caterpillars were fed with diet 2 , in which the average duration of this phase was $13.6 \pm 0.004$ days (Table 2).

Regarding the duration of the adult phase for males, there were no statistically significant differences for adults fed in the larval phase with diets 2,3 and 4, with mean values in days of $15.08 \pm 0.013,14.6 \pm 0.004$ and $15.0 \pm 0.008$, respectively. However, males from diet 1 in the larval phase had a shorter life span $(13.74 \pm 0.009)$.

In Figure 2, it is observed that the larval viability was $100 \%$ for diets 1, 2 and 4 and $95.33 \%$ for diet 3, and the caterpillars in this diet started to die at the last instar, between the sixteenth and seventeenth day.

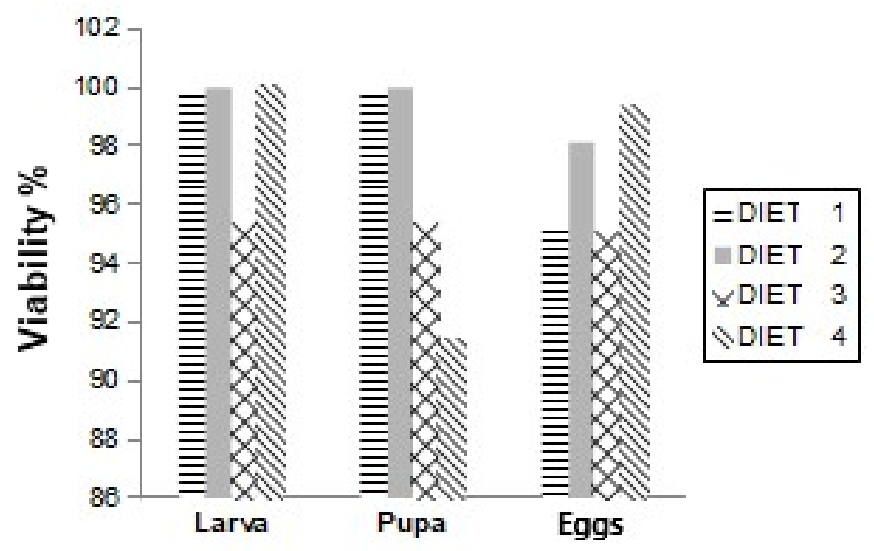

Figure 2. Viability of larva, pupa and eggs C. vestigialis: whose larvae were fed the different artificial diets.

Figura 2. Viabilidade de larva, pupa e ovos C. vestigialis: cujas larvas foram alimentadas com as diferentes dietas artificiais.

The viability of pre-pupae of C. vestigialis from all tested artificial diets was $100 \%$. No mortality was found in the pre-pupal phase. The viability of the pupal phase of C. vestigialis (Figure 2), was above $91 \%$ for all tested diets, respectively: $91.33 \%$ in diet 4; 95.33\% in diet 3; and 100\% in diets 1 and 2 (Figure 2).

The viability of C. vestigialis eggs was greater when the insects were fed with diet 4, with $99.31 \%$, followed by diet 2 with $98.13 \%$. The viability obtained by diets 1 and 3 were lower than the others, with $95.33 \%$ and $95.13 \%$ respectively.

Diet 2 of this work was the one with the largest mass of pupae with $0.1179 \mathrm{~g}$, followed by diets 4,3 and 1 were those that obtained pupae masses with $0.0996 \mathrm{~g}, 0.0988 \mathrm{~g}$ and $0.0877 \mathrm{~g}$ respectively (Table 3 ).

Table 3. Average mass, in grams of the pupae of $C$. vestigialis, whose larvae were fed the different artificial diets tested. $\mathrm{N}=100$.

Tabela 3. Massa média, em gramas das pupas de C. vestigialis, cujas larvas foram alimentadas com as diferentes dietas artificiais testadas. $\mathrm{N}=100$

\begin{tabular}{lc}
\hline \multicolumn{1}{c}{ Diet } & Average pupal mass $(\mathbf{g})$ \\
\hline Diet 1 & $0,0877 \pm 0,0006 \mathrm{c}$ \\
Diet 2 & $0,1179 \pm 0,0012 \mathrm{a}$ \\
Diet 3 & $0,0988 \pm 0,0010 \mathrm{~b}$ \\
Diet 4 & $0,0996 \pm 0,0015 \mathrm{~b}$ \\
\hline F & $101,45^{* *}$ \\
CV $(\%)$ & 3,98 \\
\hline
\end{tabular}

NOTE: ** Significant at $1 \%$ probability of error. Means followed by the same letter in the columns do not differ statistically from each other, at the level of $5 \%$ probability by the Tukey test.

The adult sex ratio of C. vestigialis (Table 3) was 0.52 for insects fed diets 1 and 2 in their larval stage. For insects fed with diet 4 , the value obtained was 0.55 . The sex ratio of insects fed with diet 3 was 0.63 , and therefore, a greater proportion of emergence of females of C. vestigialis in relation to males (Table 3).

FLORESTA, Curitiba, PR, v. 51, n. 1, p. 146-153, jan/mar 2021.

Chirinzane, C. J. et.al.

ISSN eletrônico 1982-4688

DOI: $10.5380 /$ rf.v51 i1. 67580 
Table 4. Sex ratios of $C$. vestigialis adults from larvae fed on artificial diets tested.

Tabela 4. Razão sexual de adultos de $C$. vestigialis, oriundos de larvas alimentadas com as dietas artificiais testadas.

\begin{tabular}{rc}
\hline Diet & Sex ratio \\
\hline Diet 1 & 0,52 \\
Diet 2 & 0,52 \\
Diet 3 & 0,63 \\
Diet 4 & 0,55 \\
\hline
\end{tabular}

It was observed that the females of $C$. vestigialis obtained from the tested artificial diets began to perform the first laying between the second and third days after the emergence of the couples, with the majority of the females starting their laying on the second day.

Females from caterpillars fed with diet 2 had a higher number of eggs, 24,742 eggs in total during their adult life, with 24,280 being considered viable and 462 eggs were considered unfeasible. Viable eggs are those that, under a stereomicroscope, are not hollow or withered, and golden yellow in color, while non-viable eggs have hollow or withered appearance, and white in color. Females that were fed with diet 2 obtained an average of 618.55 eggs per tube, per day, with an average of 123.71 eggs per day per female (Table 5).

Table 5. Total viable and non-viable eggs; number of eggs per cage / day, number of eggs / day / female of $C$. vestigialis, from adults obtained in the different artificial diets tested.

Tabela 5. Total de ovos viáveis e inviáveis; número de ovos por gaiola/dia, número de ovos/dia/fêmea de C. vestigialis, oriundos de adultos obtidos nas diferentes dietas artificiais testadas.

\begin{tabular}{lccccc}
\hline Diets & \multicolumn{5}{c}{ TOTAL EGGS } \\
\cline { 2 - 6 } & $\begin{array}{c}\text { Viable } \\
\text { ones }\end{array}$ & $\begin{array}{c}\text { Unviable } \\
\text { ones }\end{array}$ & Sum & Cage / Day & $\begin{array}{l}\text { Eggs / day / } \\
\text { female }\end{array}$ \\
\hline Diet 1 & 8.296 & 406 & 8.702 & 217,55 & 43,51 \\
Diet 2 & 24.280 & 462 & 24.742 & 618,55 & 123,71 \\
Diet 3 & 10.424 & 542 & 10.966 & 274,15 & 54,83 \\
Diet 4 & 14.112 & 98 & 14.210 & 355,25 & 71,05 \\
\hline
\end{tabular}

Females from caterpillars fed with diet 1, had the least number of eggs laid, 8,702 eggs in all, with 8,296 eggs being considered viable and 406 not viable. The average was 217.55 eggs per tube per day, with $43.51 \mathrm{eggs}$ per female / day (Table 5).

Table 5 shows that in females from diet 3, the percentage of viable eggs was $95.05 \%$. In this diet, an average of 274.15 eggs per tube per day was placed, with 54.83 eggs per tube per day per female, with a total of 10,966 eggs.

\section{DISCUSSION}

The five larval instars verified in this work, the duration of the pre-pupa stage of one day, and the duration of the pupa period of 7, 8 days on average, verified in this work are similar to the result found by Campos et al. (2017), who also tested artificial diets. in the creation of $C$. vestigialis in the laboratory, using artificial diets.

Diet 1 was the only one that did not produce pupae, by reason of the mortality that occurred in the larva phase, this diet was the only one that did not have Populus leaves in its composition, to insert in the diet the food, which is the target of the insect pest in the field, can affect the attractiveness of the larvae to the diet, as mentioned by Junior et al. (2011); Moura et al., (2012).

The observations found in this research, in relation to adult longevity, demonstrate that the females found fed with diet 2 in this research, of $13.6 \pm 0.004$ days, were similar to those found by Campos et al. (2017) in the diet considered as the best by the author who obtained it (13.6 \pm 0.4 days). Regarding male longevity Campos et al. (2017) found 17.6 days, while 15.08 days were found in this study.

AThe quality characteristics of the diet must be analyzed according to the purpose of insect creation. If the goal of mass breeding is to produce caterpillars for the multiplication of viruses, one of the most important factors is the pupae body mass (VACARI et al., 2012). As the production of the virus is the objective of this mass breeding of $C$. vestigialis, one of the indications for defining the most suitable diet for this purpose is the mass of the pupae. It can be deduced that if the pupae are heavier, they are well nourished, and heavier, consequently generating a greater amount of virus. This high weight gain is a reflection of the quality and quantity of the food eaten by the insect during the larval phase.

The sex ratio of 0.52 of $\mathrm{C}$. vestigialis whose larvae were fed on diets 1 and 2, produced a ratio very close to that

FLORESTA, Curitiba, PR, v. 51, n. 1, p. 146-153, jan/mar 2021.

Chirinzane, C. J. et.al.

ISSN eletrônico 1982-4688

DOI: 10.5380/rf.v51 i1. 67580 
of a female to a male, found in the work of Campos et al. (2017) who found the value of 0.50 for the sex ratio. A balanced proportion between males and females is an important characteristic for insect breeding, since an imbalance in this proportion can make it difficult to balance mass breeding.

Regarding posture, diet 4 although it had $99.31 \%$ viable eggs, the total number of eggs $(14,112$ eggs) was lower than that measured for females whose caterpillars were fed with diet 2, which was 24,742 eggs. This is a fact that makes this diet more likely to increase the population in the laboratory and, consequently, more larvae to subsidize the production of viruses in the new generation of moths.

\section{CONCLUSIONS}

- The four tested diets allow the development of C. vestigialis caterpillars in the laboratory to produce the entomapotogenic virus Condylorrhiza vestigialis multiple nucleopolyhedrovirus (CoveMNPV).

- Diet 2 allows the rapid and efficient increase of the population of C. vertigialis in the laboratory, and consequently greater production of viruses, considered thus the most suitable for this purpose.

\section{REFERENCES}

AMBROGUI, B. G.; FONSECA, M. G.; CORACINI, M. D. A.; ZARBIN, P. H. G. Calling behaviour and male response towards sex pheromone of poplar moth Condylorrhiza vestigialis (Lepidoptera: Crambidae). Journal of Pest Science, v. 82, n. 1, p. 55-60, 2009.

ARIOLI, C. J.; GARCIA, M. S.; ZARTE, M.; BOTTON, M. Biologia da mariposa-oriental em dieta artificial á base de milho. Scientia Agraria, Curitiba, v. 11, n. 6, p. 481-486, 2010.

BORTOLI, L. C.; JUNIOR, R. M.; BOTTON, M. Biologia e tabela de vida de fertilidade da broca-do-morangueiro criada em dieta artificial. Pesquisa agropecuária brasileira, Brasília, v.49, n. 2, p. 144-147, 2014.

BORTOLI, S. A.; TAKAHASHI, R.; VACARI, A. M.; BORTOLI, C. P.; RAMALHO, D. G.; BORTOLI, S. L. P. Efeito do oferecimento de dietas artificiais nos ínstares iniciais sobre o consumo de dieta natural e metabolismo no ínstar final de lagartas de Bombyx mori L. (Lepidoptera: Bombycidae). Comunicata Scientiae, Teresina, v. 6 , n. 2, p. 194-201, 2015.

CAMPOS, L. S; ALOISIO COELHO JR, A; PARRA, J. R. Artificial diet for laboratory rearing of condylorrhiza vestigialis (guenée, 1854) (Lep.: Crambidae). Anais da Acadêmia Brasileira de Ciências, Rio de Janeiro, v. 89 n. $1,2017$.

CASTRO, M. E. B.; RIBEIRO, Z. M.; SANTOS, A. C. B.; SOUZA, M. L.; MACHADO, E. B.; SOUSA, N. J.; MOSCARDI, F. Identification of a new nucleopolyhedrovirus from naturally-infected Condylorrhiza vestigialis (Guenée) (Lepidoptera: Crambidae) larvae on poplar plantations in South Brazil. v. 102, n. 2, p. 149-154, 2009.

CASTRO, M. E. B.; PAUlA, D. P.; AlMEIDA, G. F.; RIBEIRO, Z. M.; SOUZA, M. L.; INGLIS, P. W. Identification and sequence analysis of the Condylorrhiza vestigialis MNPV p74 gene. Virus Genes, v. 43, n. 3, p. 471-475, 2011.

JUNIOR, A. L. B.; LEONELO, A. F.; JESUS, F.G. Dietas artificiais incorporadas ou não a colmos triturados de variedades de cana-de-açúcar na biologia de Diatraea saccharalis (F.) (Lepidoptera: Crambidae). Semina, Londrina, v. 32, n. 1, p. 39-48, 2011.

MACHADO, E. B.; SOUSA, N. J.; MOSCARDI, F. Eficiência em campo de diferentes concentrações de Condylorrhiza vestigiais multiple nucleopolyhedrovirus no controle de Condylorrhiza vestigiais. Floresta, Curitiba, v. 47, n. 2, p. 207 - 212, 2017.

MARQUES, E. N.; SOUSA, N. J.; CORREA, R. de M.; GOMES, N. B. Ocorrência de Condylorrhyza vestigialis (Guenée, 1854) (Lepidoptera: Pyralidae) em povoamentos de Álamo Populus spp. No município de São Mateus do Sul - Paraná. Revista do Setor de Ciências Agrárias. Curitiba, v. 14. n. 1/2, p. 229-230, 1995.

MEDEIROS, J. G. da S.; HOPPE, J. M. Efeito da aplicação de calcário em estacas de Populus deltoides Bart. Ex Marsh. cultivadas em vaso. Ciência Florestal, Santa Maria, v. 2, p. 161 - 167, 2002.

MOURA, J. Z.; PÁDUA, L. E. M.; SILVA, P. R. R.; SILVA, A. A.; MAGGIONI, K. Extrato de folhas de Anadenanthera macrocarpa sobre a biologia de Spodoptera frugiperda criada em dieta artificial. Comunicata Scientiae. Terezina, v. 3, n. 4, p. 249-254, 2012. 
PARRA, J. R. P.; MIHSFELDT, L. H.; Comparison of artificiais diets for rearing the sugarcane borer. In: ANDERSON, T. E.; LEPPLA, N. C. Advances in insect rearing for research and pest management. San Francisco, Westview Press, 1992, 519 p.

POGETTO, M. H. F. A.; WILCKEN, C. F. The effect of Beauveria bassiana on brazilian poplar moth Condylorrhiza vestigialis (Lepidoptera: Crambidae). Journal of Plant Protection Research, v. 52, n. 1, p. 10-14, 2012.

SILVEIRA NETO, S.; SILVEIRA NETO, S.; NAKANO, O.; BARBIN, D.; VILLA NOVA, N. A. Manual de ecologia dos insetos. São Paulo: Ed. Ceres, 1976, 419 p.

VACARI, A. M.; GENOVEZ, G. S.; LAURENTIS, V. L.; BORTOLI, S. A. Fonte proteica na criação de Diatraea saccharalis e seu reflexo na produção e no controle de qualidade de Cotesia flavipes. Bragantia, Campinas, v. 71, n. 3, p. 355-361, 2012. 